\title{
Penggunaan Biji Asam Jawa (Tamarindus indica L.) dan Biji Kecipir (Psophocarpus tetragonolobus L.) Sebagai Koagulan Alami Dalam Perbaikan Kualitas Air Tanah
}

\author{
Hendrawati $^{1}$. Delsy Syamsumarsih ${ }^{1}$. Nurhasni ${ }^{1}$ \\ Program Studi Kimia Fakultas Sains dan Teknologi UIN Syarif Hidayatullah Jakarta, \\ Jalan Ir. H. Juanda No. 95, Ciputat 15412 Indonesia. Telp. (62-21) 7493606 \\ Email : hendrawati.wibowo@yahoo.co.id
}

\begin{abstract}
Abstrak
Penggunaan Biji Asam Jawa (Tamarindus indica L.) dan Biji Kecipir (Psophocarpus tetragonolobus L.) Sebagai Koagulan Alami dalam Perbaikan Kualitas Air Tanah telah dilakukan. Penelitian bertujuan untuk mengetahui kemampuan serbuk biji asam jawa dan biji kecipir sebagai biokoagulan untuk memperbaiki kualitas air dan pengaruhnya terhadap parameter kualitas air, yang meliputi: temperatur, $\mathrm{pH}$, konduktivitas, kekeruhan, oksigen terlarut, kandungan logam berat, dan total koliform. Hasil jar test diperoleh dosis optimum 0,009\% (penurunan turbiditas 99,72\%) untuk biji asam jawa dan 0,03\% (penurunan turbiditas 92,03\%) untuk ekstrak biji kecipir. Nilai pH optimum diperoleh pada $\mathrm{pH} 3$ untuk kedua jenis biokoagulan. Penggunaan ekstrak biji asam jawa dan biji kecipir dan tidak memberikan pengaruh yang berarti terhadap parameter temperatur, $\mathrm{pH}$, konduktivitas,dan logam berat. Penggunaan ekstrak biji kecipir dan biji asam jawa tidak menurunkan angka BOD. Ekstrak biji asam jawa mampu menurunkan angka total koliform sedangkan ekstrak biji kecipir tidak efektif dalam menurunkan angka total koliform.
\end{abstract}

Kata Kunci: Koagulasi, Asam jawa (Tamarindus indica L.), Kecipir (Psophocarpus tetragonolobus L.), Jar test, Air tanah, MPN.

\begin{abstract}
Abstrack
The Use of Tamarind Seeds (Tamarindus indica L.) and Winged Bean Seeds (Psophocarpus tetragonolobus L.) As Natural Coagulant in Groundwater Quality Improvementhas been done. The aims of this study is to determine the ability of tamarind seeds and winged bean seeds as biocoagulant to improve water quality and its effect on water quality parameters, which include: temperature, $\mathrm{pH}$, conductivity, turbidity, dissolved oxygen, heavy metal content, and total coliform. Jar test results obtained optimum dose of $0.009 \%$ (99.72\% reduction in turbidity) to tamarind seeds and $0.03 \%$ (92.03\% reduction in turbidity) to winged bean seeds. The optimum pH obtained at $\mathrm{pH} 3$ for both types of biocoagulant. The use of tamarind seeds and winged bean seeds does not have much influence on the parameters of temperature, $\mathrm{pH}$, conductivity, and heavy metals. They also did not reduce the number of BOD. Tamarind seeds reduce the number of total coliform while winged bean seeds are not effective in reducing the number of total coliform.
\end{abstract}

Keywords: Coagulation, Tamarind (Tamarindus indica L.), Winged bean (Psophocarpus tetragonolobus L.), Jar test, Groundwater, MPN.

\section{PENDAHULUAN}

Air sebagai sumber daya alam yang sangat penting, dibutuhkan di berbagai bidang kehidupan dan berbagai kegiatan masyarakat untuk kelangsungan hidup sehingga keberadaan air sangat mutlak diperlukan. Tanpa adanya proses pengolahan air yang memadai, air yang sudah tercemar dapat membebani bahkan 
melampaui kesanggupan alam untuk membersihkannya. Proses pengolahan air yang memadai merupakan salah satu kunci dalam memelihara kelestarian lingkungan.

Pencemaran utama pada air diakibatkan oleh limbah rumah tangga, limbah industri, dan limbah pertanian. Cemaran tersebut dapat mencemari mikroorganisme dan lingkungannya baik dalam bentuk larutan, koloid, maupun bentuk partikel lainnya. Oleh karena itu, mengingat penting dan besarnya dampak yang ditimbulkan bagi lingkungan maka dibutuhkan metode yang tepat untuk mengolah air.

Pengolahan air dapat dilakukan dengan berbagai metode seperti presipitasi, adsorpsi, dan koagulasi. Di antara metode yang ada, metode koagulasi merupakan salah satu metode yang cukup banyak diaplikasikan pada pengolahan air. Pada metode ini biasanya digunakan suatu koagulan sintetik. Koagulan yang umumnya dipakai adalah garam-garam aluminium seperti aluminium sulfat dan PAC (polyaluminium chloride). Beberapa studi melaporkan bahwa aluminium, senyawa alum, dapat memicu penyakit Alzheimer (Campbell, 2002). Dilaporkan juga bahwa monomer beberapa polimer organik sintetik seperti PAC dan Alum memiliki sifat neurotoksisitas.

Alternatif lain dari penggunaan koagulan sintetik yaitu pemanfaatan biokoagulan yang berasal dari bahan-bahan yang tersedia di alam. Dalam rangka menggiatkan pemanfaataan bahan-bahan alami sebagai biokoagulan dan lebih merperkaya keragaman tanaman yang berpotensi sebagai alternatif koagulan sintetik, telah dilakukan beberapa penelitian terhadap tanaman yang memiliki potensi sebagai biokoagulan diantaranya biji kelor (Moringa oleifera) (Foidl et al.,; Bina et al., 2010; Yuliastri dan Hendrawati, 2010), biji asam jawa (Tamarindus indica L.) (Enrico, 2008), dan biji nirmali (Strychnos potatorum) (Babu dan Malay Chauduri, 2005).

Tanaman lain yang diduga memiliki potensi sebagai biokoagulan di antaranya biji asam jawa (Tamarindus indica L.) dan biji kecipir (Psophocarpus tetragonolobus L.) yang keduanya berasal dari famili Fabaceae. Salah satu penelitian sebelumnya menyebutkan bahwa penggunaan kacang babi (Vicia faba), juga berasal dari famili Fabaceae, efektif dalam memperbaiki sifat fisik dan kimiawi limbah cair industri pulp dan kertas (Saefudin et al., 2006). Biji asam jawa dan biji kecipir memiliki kandungan protein yang cukup tinggi yang juga dimiliki oleh biji kelor dan biji kacang babi. Protein yang terkandung dalam biji asam jawa dan biji kecipir inilah yang diharapkan dapat berperan sebagai polielektrolit alami yang kegunaannya mirip dengan koagulan sintetik. Kecipir diharapkan dapat menjadi alternatif biokoagulan (koagulan alami) karena tanaman ini mudah dibudidayakan, pertumbuhannya cepat, dan dapat diremajakan. Selain itu, dalam proses penanamannya kecipir dapat ditanam secara tumpang sari dengan asam jawa.

Penelitian yang dilakukan bertujuan untuk mengetahui kemampuan biji asam jawa dan biji kecipir sebagai koagulan alami untuk memperbaiki kualitas air dan mengetahui pengaruh biji asam jawa dan biji kecipir terhadap parameter kualitas air, yang meliputi: kekeruhan, temperatur, $\mathrm{pH}$, konduktivitas, kandungan logam berat, total koliform, dan oksigen terlarut. Diharapkan dari penelitian ini akan diperoleh biokoagulan dari biji asam jawa dan biji kecipir sebagai alternatif bagi penggunanan koagulan sintetik.

\section{METODE PENELITIAN}

Penelitian dilaksanakan pada bulan April - September 2011. Penelitian dilakukan di Laboratoriun Kimia dan Laboratorium Biologi Pusat Lab Terpadu (PLT) UIN Syarif Hidayatullah Jakarta dan Laboratorium Balai Teknologi Lingkungan (BTL)-BPPT Serpong.

\section{Alat dan Bahan}

Peralatan yang digunakan dalam penelitian ini adalah magnetic stirrer (Heidolph MR $3001 \mathrm{~K})$, portable pH-meter and conductivitimeter (Myron LARH1), portable tubidimeter (HANNA Instrument), atomic absorption spectrophotometer (AAS) (Shimadzu AA-6800), DO-meter (SCHOTT), laminar air flow, autoclave (ALP), inkubator 
(Memmert), cuvet, tabung Durham, dan peralatan gelas lainnya.

Bahan yang digunakan dalam penelitian ini terdiri dari bahan uji (sampel) dan bahan kimia. Bahan uji terdiri dari sampel air tanah yang diambil dari sumur bor di Kampus UIN Jakarta pada bulan Juni, Juli, Agustus, dan September 2011, biji kecipir yang diambil pada bulan Maret 2011 dari daerah Cianjur, dan biji Asam jawa yang diambil pada bulan April 2011 dari daerah Karawang.

Bahan kimia yang digunakan terdiri dari Lactose Broth (Conda), aquades, asam sulfat $\left(\mathrm{H}_{2} \mathrm{SO}_{4}\right) 25 \%$, natrium hidroksida $(\mathrm{NaOH}) 10 \%$, larutan buffer $\mathrm{pH} 4$ dan 7 , natrium klorida $(\mathrm{NaCl})$ 0,1 $\mathrm{M}$ dan 0,01 $\mathrm{M}$, kadmium sulfat heptahidrat $\left(\mathrm{CdSO}_{4} .8 \mathrm{H}_{2} \mathrm{O}\right) 100 \mathrm{ppm}$, tembaga sulfat anhidrat $\left(\mathrm{CuSO}_{4}\right) 100 \mathrm{ppm}$, kromium klorida heksahidrat $\left(\mathrm{CrCl}_{3} \cdot 6 \mathrm{H}_{2} \mathrm{O}\right) 100 \mathrm{ppm}$, semua reagen adalah produksi Merck dengan kualitas p.a. (pro analisis)

\section{Persiapan Sampel}

Biji asam Jawa dan biji Kecipir yang digunakan dalam pembuatan suspensi adalah biji kecipir dan biji asam jawa yang sudah tua dan kering. Biji kecipir direndam dalam air selama \pm 12 jam kemudian dikupas kulitnya dan dikeringkan. Biji kecipir yang telah kering kemudian dihaluskan dengan blender lalu diayak diperoleh serbuk halus. Serbuk halus kecipir dibuat suspensi $2 \% \quad(\mathrm{~b} / \mathrm{v})$ dengan melarutkan 2 gram serbuk halus dengan aquades hingga volumenya $100 \mathrm{~mL}$. Suspensi kemudian disaring dengan kertas saring. Pembuatan suspensi biji kecipir sesuai dengan konsentrasi yang diinginkan dilakukan dengan cara pengenceran. Perlakuan yang sama dilakukan untuk pembuatan suspensi biji asam jawa tetapi tanpa dilakukan perendaman.

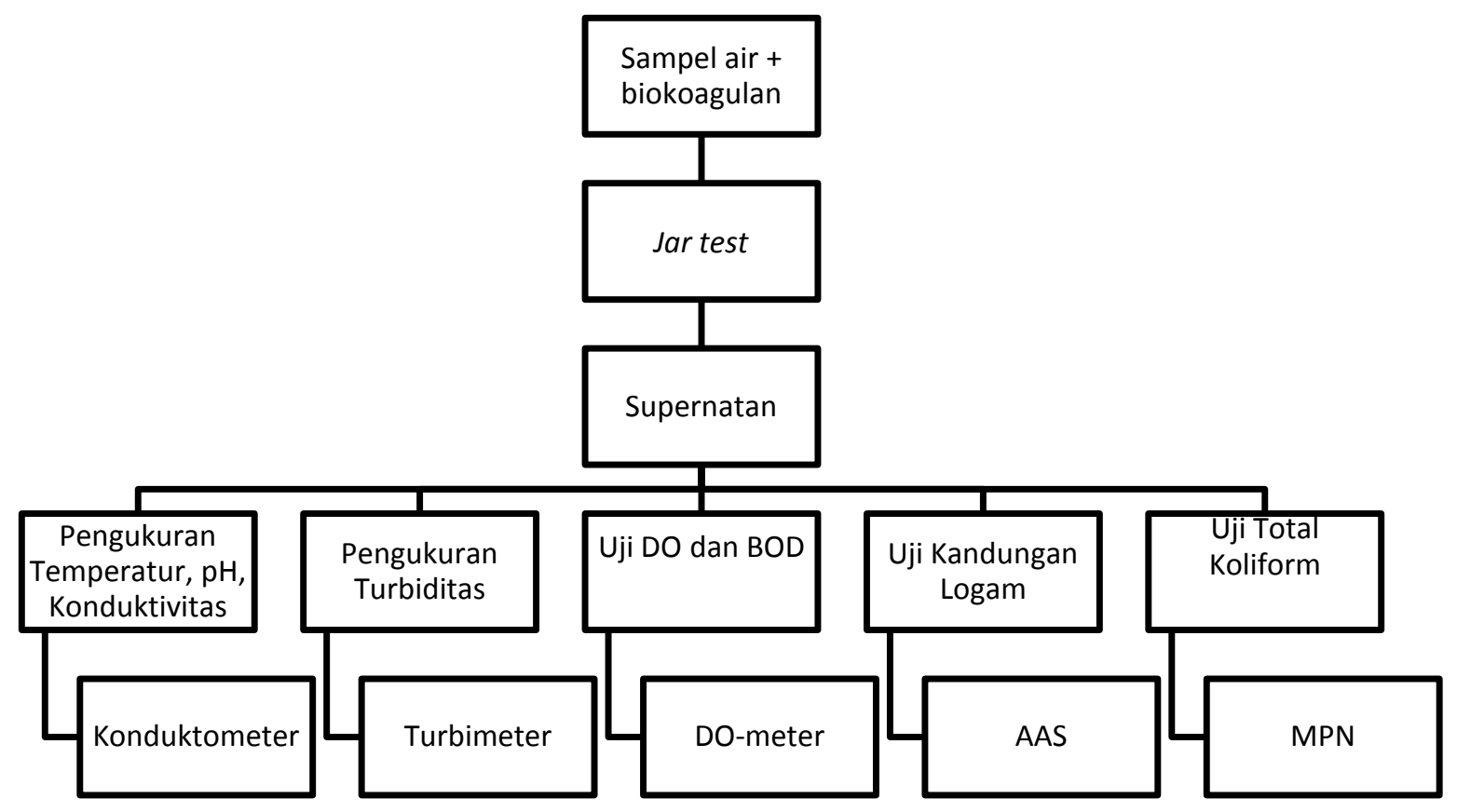

Gambar 1. Bagan alir penelitian 


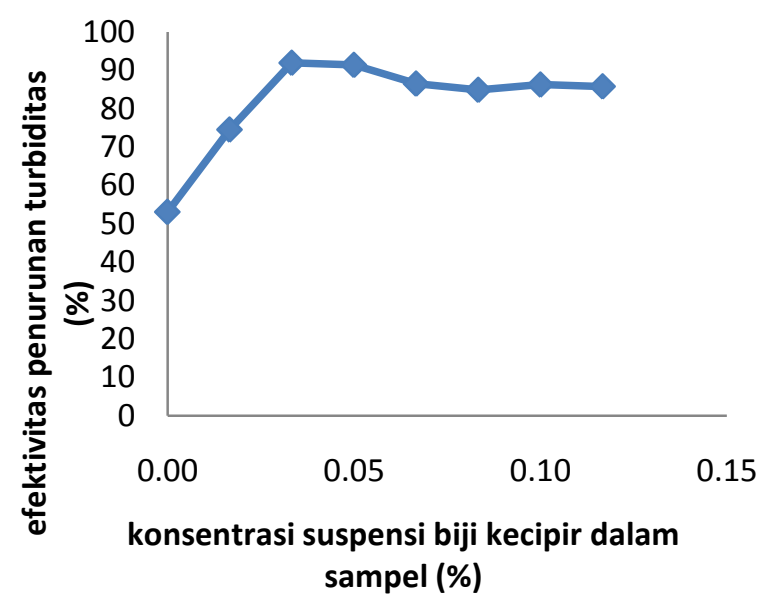

Gambar 2. Grafik pengaruh dosis biji Kecipir terhadap turbididitas

Efektivitas penurunan turbiditas pada Gambar 2 dihitung berdasarkan penurunan turbiditas sebelum dan sesudah perlakuan. Efektivitas penurunan turbiditas tertinggi diperoleh dengan penambahan konsentrasi biokoagulan $0,03 \%$ yaitu sebesar $92,03 \%$. Pada konsentrasi di atas $0,03 \%$, efektivitas penurunan turbiditas kembali menurun disebabkan penambahan biokoagulan yang berlebihan mengakibatkan bertambahnya kecenderungan flok untuk mengapung dan tidak mengendap. Kelebihan koagulan yang tidak berinteraksi dengan partikel koloid juga akan menyebabkan kekeruhan sehingga turbiditas kembali meningkat di atas dosis optimum.

Gambar 3 menunjukkan pengaruh konsentrasi biokoagulan biji asam jawa terhadap turbiditas. Sama halnya dengan biokoagulan biji kecipir, pada grafik terlihat bahwa efektivitas penurunan turbiditas yang dihasilkan semakin meningkat dengan meningkatnya konsentrasi akan tetapi terjadi penurunan kembali pada konsentrasi tertentu. Punurunan turbiditas tertinggi diperoleh dengan penambahan konsentrasi biokoagulan 0,009\% yaitu sebesar 99,72\% dan kembali terjadi penurunan pada konsentrasi $0,018 \%$. Efektivitas penurunan turbiditas pada Gambar 3 dihitung berdasarkan penurunan turbiditas sebelum dan sesudah perlakuan.

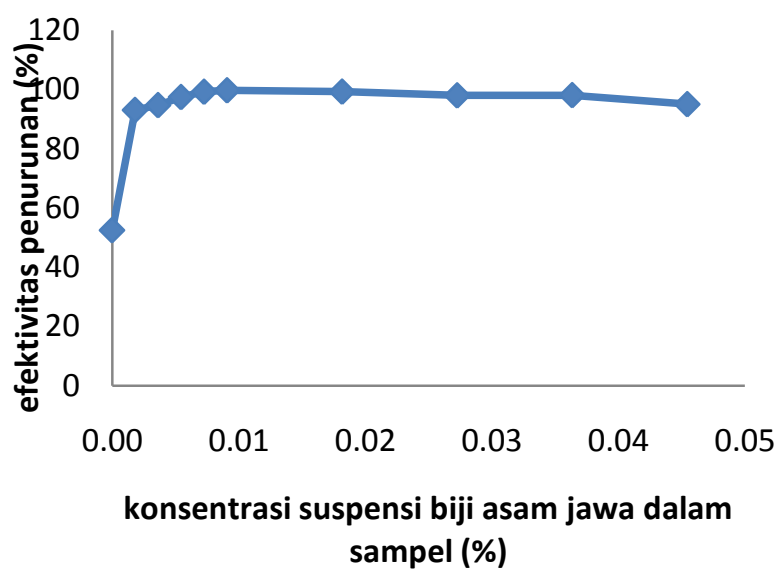

Gambar 3. Grafik pengaruh dosis biji Asam Jawa terhadap turbididitas

Meningkatnya efektivitas penurunan seiring dengan meningkatnya konsentrasi biokoagulan yang diberikan menunjukkan semakin tinggi konsentrasi polielektrolit yang diberikan efektivitas penurunan turbiditas yang dihasilkan semakin baik karena penambahan konsentrasi polielektrolit akan mengakibatkan berkurangnya kestabilan koloid dan akan mengurangi gaya tolak menolak antara partikel sehingga menunjang proses pengendapan.

Secara umum semua partikel koloid memiliki muatan sejenis. Diakibatkan muatan yang sejenis, maka terdapat gaya tolak-menolak antar partikel koloid. Hal ini mengakibatkan partikel-partikel koloid tidak dapat bergabung sehingga memberikan kestabilan pada sistem koloid. Protein yang terlarut dari biji kecipir dan asam jawa mengandung gugus $-\mathrm{NH}_{3}{ }^{+}$yang dapat mengikat partikel-partikel yang bermuatan negatif sehingga partikel-partikel tersebut terdestabilisasi membentuk ukuran partikel yang lebih besar yang akhirnya dapat terendapkan. Proses pengadukan selama jartest berlangsung juga harus diperhatikan untuk menunjang keberhasilan proses koagulasi. Pengadukan cepat (rapid mixing) berperan penting dalam pencampuran koagulan dan destabilisasi partikel. Tujuan pengadukan cepat adalah untuk menghasilkan turbulensi air sehingga dapat mendispersikan koagulan dalam 
air. Pengadukan cepat selama jar test berlangsung membantu partikel-partikel halus di dalam air saling bertumbukan sehingga membentuk mikroflok. Sedangkan pengadukan lambat (slow mixing) berperan dalam upaya penggabungan flok. Mikroflok yang telah terbentuk ini melalui pengadukan lambat akan bergabung menjadi makroflok yang dapat dipisahkan melalui sedimentasi.

\section{Pengaruh Koagulan Terhadap Temperatur Air Tanah}

Salah satu faktor yang mempengaruhi proses koagulasi adalah temperatur sehingga pengaturan temperatur perlu diperhatikan untuk memperoleh hasil yang optimum. Menurut Pernitsky (2003), temperatur rendah mempengaruhi proses flokulasi dan koagulasi dengan mengubah solubilitas koagulan, meningkatkan viskositas air, dan memperlambat kinetika reaksi hidrolisis dan flokulasi partikel.

Pada penelitian ini jar test dilakukan pada temperatur ruang tanpa mengubah temperatur sampel air. Pada Tabel 1 dan 2 dapat dilihat bahwa penambahan suspensi biokoagulan ke dalam sampel air tidak memberikan pengaruh terhadap temperatur. Hasil pengukuran temperatur terhadap sampel air sebelum dan sesudah dilakukan jar test menunjukkan tidak terdapat perubahan temperatur yang berarti. Pada sampel air dengan biokoagulan biji kecipir diperoleh temperatur awal sampel $28,30^{\circ} \mathrm{C}$ sedangkan setelah perlakuan jar test diperoleh sampel air dengan kisaran suhu $28,23-28,67^{\circ} \mathrm{C}$.

Tabel 1. Pengaruh penambahan biokoagulan biji kecipir terhadap temperatur

\begin{tabular}{cc}
\hline $\begin{array}{c}\text { Konsentrasi Kecipir } \\
\text { dalam Sampel } \\
(\%)\end{array}$ & $\begin{array}{c}\text { Temperatur } \\
\text { sesudah } \\
\text { perlakuan }\left({ }^{\circ} \mathrm{C}\right)\end{array}$ \\
\hline kontrol & $28,33 \pm 0,29$ \\
0,02 & $28,57 \pm 0,06$ \\
0,03 & $28,60 \pm 0,17$ \\
0,05 & $28,27 \pm 0,06$ \\
0,07 & $28,23 \pm 0,06$ \\
0,08 & $28,60 \pm 0,26$ \\
0,10 & $28,50 \pm 0,17$ \\
0,12 & $28,67 \pm 0,06$ \\
\hline
\end{tabular}

Tabel 2. Pengaruh penambahan biokoagulan asam jawa terhadap temperatur

\begin{tabular}{cc}
\hline $\begin{array}{c}\text { Konsentrasi Asam Jawa } \\
\text { dalam Sampel } \\
(\%)\end{array}$ & $\begin{array}{c}\text { Temperatur } \\
\text { sesudah } \\
\text { perlakuan }\left({ }^{\circ} \mathrm{C}\right)\end{array}$ \\
\hline kontrol & $28,17 \pm 0,06$ \\
0,002 & $28,00 \pm 0,00$ \\
0,004 & $27,90 \pm 0,00$ \\
0,005 & $27,83 \pm 0,06$ \\
0,007 & $27,87 \pm 0,06$ \\
0,009 & $28,20 \pm 0,00$ \\
0,018 & $28,10 \pm 0,00$ \\
0,027 & $28,10 \pm 0,00$ \\
0,036 & $27,83 \pm 0,06$ \\
0,045 & $28,63 \pm 0,29$ \\
\hline
\end{tabular}

Pada sampel air dengan biokoagulan biji asam jawa diperoleh temperatur awal sampel $28,47-28,7^{\circ} \mathrm{C}$ sedangkan setelah perlakuan jartestdiperoleh sampel air dengan kisaran suhu $27,80-28,20^{\circ} \mathrm{C}$.

\section{Pengaruh Koagulan Terhadap pH Air Tanah}

Proses koagulasi sangat dipengaruhi oleh pH. Koagulan memiliki rentang $\mathrm{pH}$ tertentu untuk mencapai koagulasi yang optimum. Misalnya, rentang $\mathrm{pH}$ optimum untuk alum adalah 4,0 sampai dengan 8,0 karena aluminium hidroksida relatif tidak larut pada rentang tersebut. Oleh karena itu, air yang akan diberi perlakuan jar test harus memiliki $\mathrm{pH}$ yang memadai untuk dapat bereaksi dengan koagulan sehingga menghasilkan flok.

Tabel 3. Pengaruh $\mathrm{pH}$ terhadap penurunan turbiditas air tanah dengan penambahan biokoagulan biji kecipir

\begin{tabular}{|c|c|c|c|}
\hline \multirow[t]{2}{*}{$\mathrm{Ph}$} & \multicolumn{2}{|c|}{ Turbiditas (NTU) } & \multirow{2}{*}{$\begin{array}{l}\text { Efektivitas } \\
\text { Penurunan } \\
\quad(\%)\end{array}$} \\
\hline & $\begin{array}{l}\text { sebelum } \\
\text { perlakuan }\end{array}$ & $\begin{array}{c}\text { sesudah } \\
\text { perlakuan }\end{array}$ & \\
\hline 2 & 27,87 & 5,38 & 80,70 \\
\hline 3 & 38,12 & 3,04 & 92,03 \\
\hline 4 & 59,33 & 8,77 & 85,22 \\
\hline 5 & 60,33 & 10,56 & 82,50 \\
\hline 6 & 63,67 & 70,00 & $-9,95$ \\
\hline
\end{tabular}

Tabel 3 dan 4 menunjukkan pengaruh $\mathrm{pH}$ pada proses koagulasi. Kedua jenis biokoagulan tersebut dapat bekerja lebih 
optimum pada $\mathrm{pH}$ asam. Pada $\mathrm{pH}$ alami sampel (pH 6) tidak terjadi pembentukan flok dengan penambahan biokoagulan ke dalam sampel sehingga tidak terjadi penurunan turbiditas, sebaliknya turbiditas sampel menjadi meningkat. Hal ini menunjukkan bahwa pada pH 6 penambahan kedua biokoagulan tidak terjadi destabilisasi partikel-partikel koloid di dalam air sehingga tidak terjadi pembentukan flok. Sedangkan pada $\mathrm{pH}$ asam diduga terjadi protonasi pada gugus amino $\left(\mathrm{NH}_{2}\right)$ dari protein yang terlarut dari biji kecipir dan biji sam jawa sehingga gugus amino berinteraksi dengan $\mathrm{H}^{+}$ dari larutan menjadi $-\mathrm{NH}_{3}{ }^{+}$. Gugus $-\mathrm{NH}_{3}{ }^{+}$ mendukung terjadinya ikatan antara protein biji kecipir dan asam jawa dengan partikel-partikel koloid yang bermuatan negatif. Efektivitas penurunan turbiditas kembali menurun pada $\mathrm{pH}$ 2 diduga telah terjadi denaturasi protein akibat $\mathrm{pH}$ yang terlalu ekstrim.

Tabel 4. Pengaruh $\mathrm{pH}$ terhadap penurunan turbiditas air tanah dengan penambahan biokoagulan biji asam jawa

\begin{tabular}{|c|c|c|c|}
\hline \multirow[t]{2}{*}{$\mathrm{pH}$} & \multicolumn{2}{|c|}{ Turbiditas (NTU) } & \multirow{2}{*}{$\begin{array}{c}\text { Efektivitas } \\
\text { penurunan } \\
(\%)\end{array}$} \\
\hline & $\begin{array}{c}\text { sebelum } \\
\text { perlakuan }\end{array}$ & $\begin{array}{c}\text { sesudah } \\
\text { perlakuan }\end{array}$ & \\
\hline 2 & 27,87 & 5,67 & 79,66 \\
\hline 3 & 119,33 & 0,33 & 99,72 \\
\hline 4 & 70,33 & 6,36 & 90,95 \\
\hline 5 & 72,33 & 15,27 & 78,89 \\
\hline 6 & 61,33 & 65,33 & $-6,52$ \\
\hline
\end{tabular}

Berdasarkan Peraturan Pemerintah No. 82 Tahun 2001 Tentang Pengelolaan Kualitas Air dan Pengendalian Pencemaran Air, kriteria $\mathrm{pH}$ air bersih (Kelas II) yang dianjurkan yaitu memiliki pH 6-9 maka sampel air tanah yang telah mengalami perlakuan dengan biokoagulan biji kecipir dan asam jawa ini masih perlu melalui proses netralisasi agar pHnya sesuai dengan syarat-syarat air bersih yang dianjurkan.

\section{Pengaruh Koagulan Terhadap Konduktivitas Air Tanah}

Konduktivitas larutan dipengaruhi oleh ion-ion dalam larutan. Oleh karena itu, konduktivitas meningkat apabila konsentrasi ion meningkat. Untuk menghantarkan arus listrik, ion-ion bergerak dalam larutan memindahkan muatan listriknya (ionic mobility) yang bergantung pada ukuran dan interaksi antar ion dalam larutan.

Berdasarkan Tabel 5 dan 6 dapat dilihat bahwa terjadi penurunan konduktivitas pada sampel air sesudah penambahan biokoagulan biji kecipir dan biji asam jawa.

Tabel 5. Pengaruh penambahan biokoagulan biji kecipir terhadap konduktivitas

\begin{tabular}{cc}
\hline $\begin{array}{c}\text { Konsentrasi Kecipir } \\
\text { dalam Sampel } \\
(\%)\end{array}$ & $\begin{array}{c}\text { Konduktivitas } \\
\text { sesudah } \\
\text { perlakuan }(\mu \mathrm{S})\end{array}$ \\
\hline Kontrol & $520,67 \pm 2,31$ \\
0,02 & $455,00 \pm 4,36$ \\
0,03 & $436,00 \pm 1,73$ \\
0,05 & $424,33 \pm 2,89$ \\
0,07 & $410,00 \pm 3,61$ \\
0,08 & $398,67 \pm 1,53$ \\
0,10 & $389,00 \pm 1,00$ \\
0,12 & $381,67 \pm 1,53$ \\
\hline
\end{tabular}

Tabel 6. Pengaruh penambahan biokoagulan biji asam jawa terhadap konduktivitas

\begin{tabular}{cc}
\hline $\begin{array}{c}\text { Konsentrasi Asam Jawa } \\
\text { dalam Sampel } \\
(\%)\end{array}$ & $\begin{array}{c}\text { Konduktivitas } \\
\text { sesudah } \\
\text { perlakuan }(\mu \mathrm{S})\end{array}$ \\
\hline Kontrol & $452,00 \pm 0,00$ \\
0,002 & $437,33 \pm 1,15$ \\
0,004 & $436,67 \pm 0,58$ \\
0,005 & $436,33 \pm 1,15$ \\
0,007 & $436,33 \pm 1,15$ \\
0,009 & $435,33 \pm 1,15$ \\
0,018 & $430,67 \pm 2,31$ \\
0,027 & $430,67 \pm 1,53$ \\
0,036 & $429,00 \pm 1,73$ \\
0,045 & $575,00 \pm 1,73$ \\
\hline
\end{tabular}


Tabel 7. Pengaruh $\mathrm{pH}$ terhadap konduktivitas

\begin{tabular}{ccccc}
\hline $\mathrm{pH}$ & \multicolumn{2}{c}{ Asam jawa } & \multicolumn{2}{c}{ Kecipir } \\
\cline { 2 - 5 } & $\begin{array}{c}\text { Kond. sebelum } \\
(\mu \mathrm{S})\end{array}$ & $\begin{array}{c}\text { Kond. sesudah } \\
(\mu \mathrm{S})\end{array}$ & $\begin{array}{c}\text { Kond. sebelum } \\
(\mu \mathrm{S})\end{array}$ & $\begin{array}{c}\text { Kond. sesudah } \\
(\mu \mathrm{S})\end{array}$ \\
\hline 2 & $4843 \pm 11,55$ & $4420 \pm 59,52$ & $4843 \pm 11,55$ & $4063 \pm 55,08$ \\
3 & $479 \pm 2,52$ & $435 \pm 1,15$ & $542,00 \pm 8,00$ & $436,00 \pm 1,73$ \\
4 & $349 \pm 0,58$ & $316 \pm 0,00$ & $443,67 \pm 2,08$ & $375,67 \pm 1,15$ \\
5 & $262 \pm 0,58$ & $241 \pm 1,15$ & $390,33 \pm 0,58$ & $333,33 \pm 1,15$ \\
6 & $191 \pm 0,62$ & $170 \pm 0,17$ & $193,77 \pm 0,31$ & $164,37 \pm 0,35$ \\
\hline
\end{tabular}

Penurunan nilai konduktivitas menunjukkan terjadinya penurunan konsentrasi ion di dalam sampel air. Penurunan konsentrasi ion ini akibat terjadinya interaksi antara ion-ion dengan senyawa polielektrolit dari biokoagulan. Ion-ion yang sudah berikatan dengan senyawa polielektrolit tidak dapat lagi menghantarkan arus listrik sehingga konduktivitas larutan menjadi berkurang.

Pada Tabel 7 dapat diamati pengaruh $\mathrm{pH}$ terhadap konduktivitas yang menunjukkan bahwa semakin mendekati $\mathrm{pH} 2$ maka nilai konduktivitas semakin meningkat. Pengukuran pengaruh $\mathrm{pH}$ terhadap konduktivitas ini dilakukan dengan dosis optimum masingmasing biokoagulan yang telah diperoleh pada jar test. Penambahan biokoagulan pada sampel air dengan rentang $\mathrm{pH}$ yang berbeda memberikan penurunan terhadap konduktivitas walaupun pengaruhnya tidak berarti.

Pengukuran pada rentang $\mathrm{pH}$ yang berbeda memberikan nilai konduktivitas yang juga berbeda. Semakin rendah $\mathrm{pH}$ maka nilai konduktivitas akan meningkat. Hal ini diakibatkan pada $\mathrm{pH}$ yang semakin rendah konsentrasi ion $\mathrm{H}^{+}$semakin meningkat sehingga nilai konduktivitasnya pun semakin tinggi. Ionion $\mathrm{H}^{+}$ikut berperan dalam menghantarkan listrik dalam larutan yang mengakibatkan konduktivitas meningkat pada $\mathrm{pH}$ yang rendah. Pada $\mathrm{pH}$ yang semakin asam kelarutan ion-ion logam yang terkandung dalam sampel air tanah juga akan meningkat sehingga akan mempengaruhi naiknya nilai konduktivitas pada $\mathrm{pH}$ yang semakin rendah.

Pengaruh Koagulan Terhadap Kadar Logam Pengukuran parameter kimia untuk kualitas air dapat berupa analisis ion tertentu.
Ion-ion tersebut terlarut dalam air karena terjadinya kontak antara air dengan endapanendapan mineral yang ada di alam maupun akibat kontaminasi oleh senyawa pencemar (Said dan Ruliasih, 2010). Keberadaan ion-ion logam yang berlebihan di perairan dapat menimbulkan efek toksik. Oleh karena itu, melalui proses koagulasi diharapkan dapat membantu mengurangi konsentrasi ion-ion logam yang berlebihan yang terdapat di perairan. Pada penelitian ini, analisis ion-ion logam dilakukan dengan menggunakan AAS terhadap logam $\mathrm{Fe}$ dan $\mathrm{Mn}$ pada sampel air tanah serta logam $\mathrm{Cu}, \mathrm{Cd}$, dan $\mathrm{Cr}$ pada larutan simulasi.

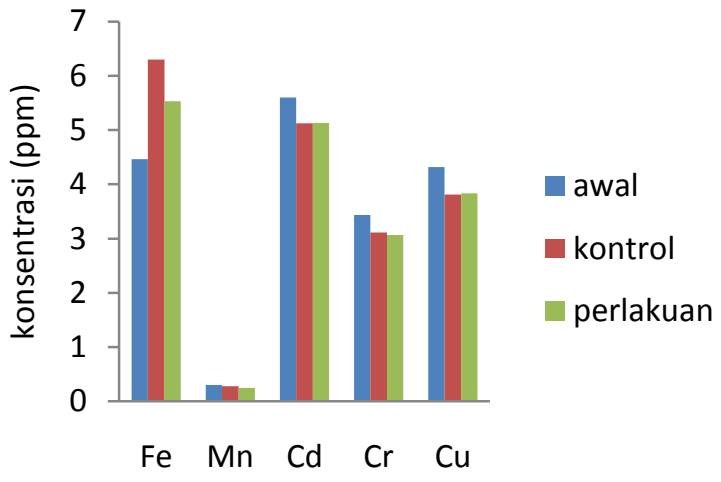

Gambar 4. Pengaruh penambahan biokoagulan biji asam jawa terhadap kandungan logam

Hasil analisis terhadap kandungan ion logam pada sampel air tanah dan larutan dapat dilihat pada Gambar 4 dan 5. Pengujian dilakukan dengan menggunakan dosis dan $\mathrm{pH}$ optimum. Hasil pengujian terhadap kandungan logam Fe ditunjukkan pada Gambar 2 dan 3. Pengujian kandungan logam Fe dalam sampel air tanah menunjukkan adanya peningkatan 
konsentrasi Fe pada kontrol dan sampel dengan perlakuan dibandingkan dengan sampel awal. Nilai $\mathrm{pH}$ larutan yang asam juga mempengaruhi kenaikan konsentrasi Fe. Pada $\mathrm{pH}$ asam kelarutan ion $\mathrm{Fe}$ meningkat sehingga lebih banyak ion Fe yang terdeteksi.

Air tanah sering mengandung zat besi $(\mathrm{Fe})$ dan mangan $(\mathrm{Mn})$ cukup besar. Adanya kandungan $\mathrm{Fe}$ dan Mn dalam air menyebabkan warna air tersebut berubah menjadi kuningcoklat setelah beberapa saat kontak dengan udara. Disamping dapat mengganggu kesehatan juga menimbulkan bau yang kurang enak serta menyebabkan warna kuning pada dinding bak serta bercak-bercak kuning pada pakaian. Oleh karena itu menurut Peraturan Menteri Kesehatan Nomor 416 Tahun 1990 Tentang Syarat-syarat dan Pengawasan Kualitas Air, kadar $(\mathrm{Fe})$ dalam air bersih maksimum yang diijinkan adalah 1,0 mg/L, dan kadar Mangan (Mn) dalam air bersih yang diijinkan adalah 0,5 $\mathrm{mg} / \mathrm{L}$.

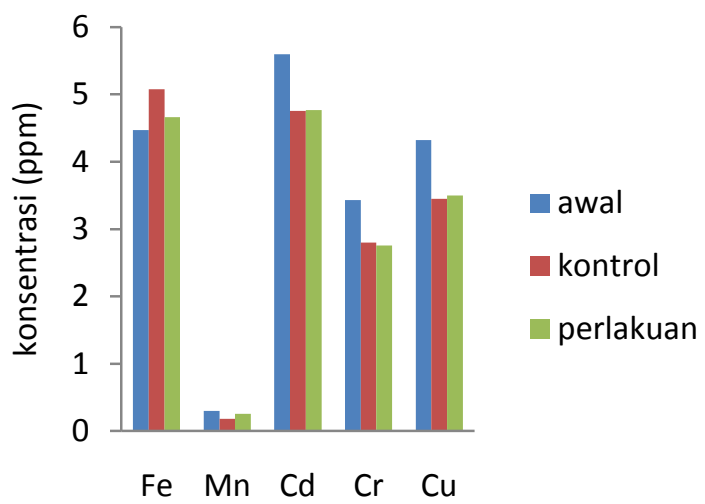

Gambar 5. Pengaruh penambahan biokoagulan biji kecipir terhadap kandungan logam

Penurunan konsentrasi logam terjadi pada logam Mn. Konsentrasi awal pada sampel air yaitu 0,2972 ppm sedangkan setelah perlakuan menjadi $0,2444 \mathrm{ppm}$ di mana terjadi penurunan konsentrasi sebesar 17,77\%. Mekanisme penyisihan ion logam ini dapat terjadi saat mulai terbentuknya flok pada proses koagulasi. Flok-flok yang terbentuk dan mengendap akan ikut mengendapkan logam Mn dalam sampel air sehingga terjadi penurunan konsentrasi.

Pengujian terhadap logam $\mathrm{Cu}, \mathrm{Cd}$, dan $\mathrm{Cr}$ bertujuan untuk mengetahui kemampuan kedua jenis biokoagulan untuk menurunkan kadar logam berat yang biasa terdapat dalam buangan limbah industri yang nantinya diharapkan dapat diterapkan dalam pengolahan air limbah industri.

Berdasarkan hasil analisis, dapat diketahui bahwa kedua jenis biokoagulan baik biji kecipir maupun asam jawa tidak memiliki kemampuan untuk mengurangi kandungan logam berat dalam larutan simulasi. Hal ini diduga polielektrolit yang terkandung dalam kedua jenis biokoagulan tersebut tidak memiliki gugus-gugus yang bermuatan negatif yang mampu mengikat ion-ion logam yang bermuatan positif. Adapun penurunan kadar logam pada kontrol dan sampel yang diberi perlakuan dibandingkan dengan kadar logam pada sampel awal lebih disebabkan oleh pengaruh pengenceran bukan karena penambahan suspensi biokoagulan.

\section{Pengaruh Koagulan Terhadap Total Koliform Air Tanah}

Parameter biologi air berhubungan dengan keberadaan populasi mikroorganisme akuatik di dalam air yang berakibat pada kualitas air. Akibat yang penting adalah penyebab penyakit yang ditimbulkan oleh adanya mikroorganisme patogen dalam air. Bakteri koliform merupakan indikator dalam substrat air, bahan makanan, dan sebagainya untuk kehadiran mikroorganisme berbahaya (Suriawiria, 2008). Lebih tepatnya bakteri koliform fekal adalah bakteri indikator adanya pencemaran bakteri patogen. Penentuan koliform fekal menjadi indikator pencemaran dikarenakan jumlah koloninya pasti berkorelasi positif dengan keberadaan bakteri patogen.

Tabel 8 dan 9 menunjukkan pengaruh biokogulan serbuk biji kecipir dan asam jawa terhadap pertumbuhan bakteri koliform dalam sampel air yang dilakukan dengan uji MPN. Uji MPN yang dilakukan menggunakan 9 tabung yang berisi media Lactose Broth (masing- 
masing 3 seri) yang diinkubasikan pada suhu $37^{\circ} \mathrm{C}$ selama $24-48$ jam.

Pengujian dilakukan pada $\mathrm{pH}$ alami sampel air (kisaran $\mathrm{pH}$ 6) dan pada $\mathrm{pH}$ optimum (kisaran $\mathrm{pH}$ 3). Hal ini dilakukan untuk melihat apakah $\mathrm{pH}$ sampel ikut berpengaruh terhadap pertumbuhan bakteri koliform, selain dari pengaruh biokoagulan.

Tabel 8 menunjukkan pengaruh biokoagulan serbuk biji kecipir terhadap pertumbuhan bakteri koliform dalam sampel air. Pada pH 6 terlihat bahwa biokoagulan serbuk biji kecipir tidak memiliki kemampuan dalam menghambat pertumbuhan bakteri koliform. Berdasarkan pengamatan 48 jam pada tabung tanpa biokoagulan terlihat adanya pertumbuhan bakteri koliform dengan indeks MPN per 100 $\mathrm{mL}$ sebesar 23 sedangkan pada tabung dengan biokagulan pertumbuhan bakteri koliform meningkat menjadi $>1100$.

Tabel 8. Hasil uji MPN air tanah pada pH 6 dan pH 3 dengan biokoagulan biji kecipir

\begin{tabular}{ccccc}
\hline $\begin{array}{c}\text { Kode } \\
\text { Sampel }\end{array}$ & \multicolumn{3}{c}{ Pembacaan Tabung dengan } & Indeks \\
& \multicolumn{3}{c}{ Hasil Positif } & MPN \\
& DSLB & SSLB & SSLB & per \\
& $(10 \mathrm{~mL})$ & $(1 \mathrm{~mL})$ & $(0,1 \mathrm{~mL})$ & $100 \mathrm{~mL}$ \\
\hline 48 KK6 & 3 & 0 & 0 & 23 \\
48 SK6 & 3 & 3 & 3 & $>1100$ \\
48 KK3 & 2 & 2 & 0 & 21 \\
48 SK3 & 3 & 1 & 1 & 75 \\
\hline
\end{tabular}

Hal yang sama juga terjadi pada $\mathrm{pH} 3$ yang menunjukkan terjadinya peningkatan pertumbuhan bakteri koliform pada tabung dengan biokoagulan. Setelah pengamatan 48 jam pada tabung tanpa biokoagulan terlihat adanya pertumbuhan bakteri koliform dengan indeks MPN per $100 \mathrm{~mL}$ sebesar 21 sedangkan pada tabung dengan biokagulan pertumbuhan bakteri koliform tetap 75 .

Menurut Maier et al. (2009), jika dalam air mengandung bahan organik dengan konsentrasi yang signifikan dan pada suhu tinggi, maka jumlah bakteri akan meningkat. Biji kecipir kaya akan kandungan protein yaitu sekitar 33,83 \% (Amoo et al., 2006). Protein inilah yang justru menjadi nutrisi bagi bakteri yang terdapat pada sampel air sehingga pertumbuhannya meningkat. Terjadinya peningkatan pertumbuhan bakteri koliform ini menunjukkan bahwa pada biji kecipir tidak terdapat zat yang bersifat antimikroba.

Tabel 9 menunjukkan pengaruh biokoagulan serbuk biji asam jawa terhadap pertumbuhan bakteri koliform dalam sampel air. Pada $\mathrm{pH} \quad 6$ terlihat adanya pengaruh penambahan biokoagulan serbuk biji asam jawa terhadap penurunan aktivitas bakteri koliform. Berdasarkan pengamatan pada 48 jam, tabung dengan biokogulan menunjukkan indeks MPN per $100 \mathrm{~mL}$ sebesar 9 yang harganya lebih rendah dibandingkan pada tabung tanpa biokoagulan yaitu 23 .

Tabel 9. Hasil uji MPN air tanah pada pH 6 dan $\mathrm{pH} 3$ dengan biokoagulan biji asam jawa

\begin{tabular}{ccccc}
\hline $\begin{array}{c}\text { Kode } \\
\text { Sampel }\end{array}$ & \multicolumn{3}{c}{$\begin{array}{c}\text { Pembacaan Tabung dengan } \\
\text { Hasil Positif }\end{array}$} & $\begin{array}{c}\text { Indeks } \\
\text { MPN } \\
\end{array}$ \\
\cline { 2 - 4 } & DSLB & SSLB & SSLB & per \\
& $(10 \mathrm{~mL})$ & $(1 \mathrm{~mL})$ & $(0,1 \mathrm{~mL})$ & $100 \mathrm{~mL}$ \\
\hline 48 KA6 & 3 & 0 & 0 & 23 \\
48 SA6 & 2 & 0 & 0 & 9 \\
48 KA3 & 3 & 0 & 0 & 23 \\
48 SA3 & 0 & 0 & 0 & 0 \\
\hline
\end{tabular}

Pada $\mathrm{pH} 3$ juga terlihat penurunan indeks MPN per $100 \mathrm{ml}$ dengan adanya penambahan biokogulan serbuk biji asam jawa. Berdasarkan pengamatan pada 48 jam, tabung tanpa biokoagulan menunjukkan indeks MPN per $100 \mathrm{~mL}$ sebesar 23 sedangkan tabung dengan biokoagulan tidak tampak pertumbuhan bakteri koliform yang ditunjukkan dengan tidak adanya tabung dengan hasil positif sehingga indeks MPN per $100 \mathrm{~mL}$ menjadi nol.

Terjadinya penurunan pertumbuhan bakteri koliform ini menunjukkan bahwa pada biji asam jawa terdapat zat yang bersifat antibakteri. Berdasarkan hasil penelitian Imbabi et al. (1992), dilaporkan bahwa ekstrak biji asam jawa memiliki kemampuan bakterisida dan fungisida yang dihasilkan oleh senyawa tamarindineal (5-hydroxy-2-oxo-hexa-3,5dineal). 
<smiles>C=C(O)/C=C\C(=O)C=O</smiles>

Gambar 6. Tamarindineal

pH memiliki peranan yang penting pada pertumbuhan mikroba. Pada umumya mikroba menyukai $\mathrm{pH}$ netral untuk pertumbuhannya. Beberapa mikroba dapat hidup pada $\mathrm{pH}$ tinggi (alkaliphils) tetapi hanya sedikit mikroba yang dapat hidup pada $\mathrm{pH}$ asam (acidophils). Berdasarkan hasil uji MPN yang dilakukan pada $\mathrm{pH} 6$ dan 3 terlihat adanya pengaruh $\mathrm{pH}$ terhadap pertumbuhan bakteri koliform selain pengaruh penambahan biokoagulan. Pada $\mathrm{pH} 3$ pertumbuhan bakteri koliform memiliki indeks MPN yang lebih rendah dibandingkan pada $\mathrm{pH}$ 6. Hal ini menunjukkan bahwa pada $\mathrm{pH} 3$ terdapat lebih sedikit mikroba yang masih dapat bertahan hidup.

\section{Pengaruh Koagulan Terhadap DO (Dissolve Oxygen) dan BOD (Biological Oxygen Demand) Air Tanah}

Keberadaan oksigen sangat vital dalam perairan alami. Dalam air oksigen dikonsumsi secara cepat oleh bahan organik, $\left(\mathrm{CH}_{2} \mathrm{O}\right)$, dalam reaksi:

$$
\left(\mathrm{CH}_{2} \mathrm{O}\right)+\mathrm{O}_{2} \rightarrow \mathrm{CO}_{2}+\mathrm{H}_{2} \mathrm{O}
$$

Parameter oksigen terlarut memberikan indikasi tentang tingkat kesegaran air akibat adanya proses biodegradasi dan asimilasi pada badan air. Adanya muatan bahan organik yang berlebih akan menyebabkan oksigen terlarut dalam air pada kondisi yang kritis, atau merusak kadar kimia air. Rusaknya kadar kimia air tersebut akan berpengaruh terhadap fungsi dari air (Salmin, 2008).

Tabel 10 menunjukkan pengaruh biokoagulan biji kecipir dan asam jawa terhadap nilai DO dan BOD. Hasil analisis menunjukkan penambahan kedua jenis biokoagulan ke dalam sampel air tidak menurunkan angka BOD.
Tabel 10. Pengaruh biokoagulan biji kecipir dan biji asam jawa terhadap nilai DO dan $\mathrm{BOD}_{5}$

\begin{tabular}{lccc}
\hline Sampel & $\begin{array}{c}\mathrm{DO}_{0} \\
(\mathrm{mg} / \mathrm{L})\end{array}$ & $\begin{array}{c}\mathrm{DO}_{5} \\
(\mathrm{mg} / \mathrm{L})\end{array}$ & $\begin{array}{c}\mathrm{BOD}_{5} \\
(\mathrm{mg} / \mathrm{L})\end{array}$ \\
\hline $\begin{array}{l}\text { Air tanah tanpa } \\
\text { perlakuan }\end{array}$ & 5,55 & 4,53 & 1,49 \\
\hline \multicolumn{2}{l}{ Air tanah + Asam jawa } & & \\
\hline $\begin{array}{l}\text { Kontrol } \\
\text { Perlakuan }\end{array}$ & 5,34 & 5,03 & 0,02 \\
\hline Air tanah + Kecipir & 5,96 & 4,85 & 1,59 \\
\hline $\begin{array}{l}\text { Kontrol } \\
\text { Perlakuan }\end{array}$ & 5,45 & 4,41 & 1,47 \\
\hline
\end{tabular}

Penurunan nilai DO pada hari kelima menunjukkan adanya peningkatan penggunaan oksigen untuk mengoksidasikan bahan organik pada sampel sehingga kadar oksigen terlarut menjadi lebih rendah. Pada sampel air tanah dengan perlakuan biji asam jawa memiliki nilai $\mathrm{BOD}_{5} 1,59 \mathrm{mg} / \mathrm{L}$ di mana terjadi kenaikan nilai $\mathrm{BOD}_{5}$ dibandingkan dengan sampel air tanah tanpa perlakuan yang memiliki nilai $\mathrm{BOD}_{5} 1,49$ $\mathrm{mg} / \mathrm{L}$. Kenaikan nilai $\mathrm{BOD}_{5}$ juga terjadi pada sampel air tanah dengan perlakuan biji kecipir dengan nilai $\mathrm{BOD}_{5} 11,5 \mathrm{mg} / \mathrm{L}$. Nilai BOD yang meningkat pada sampel dengan perlakuan menunjukkan bahwa penambahan kedua jenis biokoagulan dalam sampel air menambah muatan bahan organik yang berada di dalam sampel air sehingga dibutuhkan lebih banyak oksigen untuk mengoksidasikan bahan-bahan organik tersebut yang mengakibatkan oksigen terlarut di dalam sampel air semakin berkurang.

Nilai $\mathrm{BOD}_{5}$ yang lebih tinggi pada sampel air tanah dengan perlakuan biji kecipir dibandingkan dengan perlakuan biji asam jawa menunjukkan kebutuhan oksigen pada perlakuan dengan biji kecipir lebih tinggi yang mengindikasikan lebih banyak bahan organik yang didegradasi oleh mikroorganisme dalam sampel air dengan perlakuan biji kecipir. Hal ini berhubungan dengan kandungan biokoagulan biji asam jawa yang memiliki sifat antimikroba yang dapat mengakibatkan kematian mikroorganisme yang berperan untuk mendegradasikan bahan organik dalam sampel. Akibatnya kadar oksigen terlarut pada perlakuan biji asam jawa masih lebih tinggi dan nilai $\mathrm{BOD}_{5}$ lebih rendah dibandingkan dengan perlakuan biji kecipir. 
Tabel 11. Hasil pengujian beberapa parameter sampel dibandingkan dengan PP No. 82 Tahun 2001 dan Permenkes No.416 Tahun 1990

\begin{tabular}{|c|c|c|c|c|c|c|c|}
\hline No. & Parameter & Satuan & $\begin{array}{l}\text { Kadar } \\
\text { Maks. }\end{array}$ & Kontrol & $\begin{array}{l}\text { Kecipir } \\
(0,03 \%)\end{array}$ & Kontrol & $\begin{array}{c}\text { Asam jawa } \\
(0,009 \%)\end{array}$ \\
\hline & \multicolumn{7}{|l|}{ Fisika } \\
\hline 1 & Temperatur & ${ }^{\circ} \mathrm{C}$ & $\begin{array}{l}\text { Suhu } \\
\text { udara } \\
\pm 3^{\circ} \mathrm{C}\end{array}$ & $28,30 \pm 0,17$ & $28,60 \pm 0,17$ & $28,17 \pm 0,06$ & $28,20 \pm 0,00$ \\
\hline \multirow[t]{2}{*}{2} & Kekeruhan & NTU & 25 & $17,86 \pm 0,11$ & $3,04 \pm 0,14$ & $11,68 \pm 0,17$ & $0,33 \pm 0,03$ \\
\hline & \multicolumn{7}{|l|}{ Kimia } \\
\hline 3 & $\mathrm{pH}$ & - & $6-9$ & $3,01 \pm 0,02$ & $3,12 \pm 0,03$ & $3,13 \pm 0,02$ & $3,07 \pm 0,02$ \\
\hline 4 & Daya hantar & - & - & $520,67 \pm 2,31$ & $436,00 \pm 1,73$ & $452,00 \pm 0,00$ & $435,33 \pm 1,15$ \\
\hline 5 & Besi & $\mathrm{mg} / \mathrm{l}$ & 1,0 & $5,08 \pm 0,07$ & $4,66 \pm 0,08$ & $6,30 \pm 0,04$ & $5,53 \pm 0,08$ \\
\hline 6 & Mangan & $\mathrm{mg} / \mathrm{l}$ & 0,5 & $0,18 \pm 0,008$ & $0,26 \pm 0,009$ & $0,28 \pm 0,006$ & $0,24 \pm 0,004$ \\
\hline \multirow[t]{2}{*}{7} & BOD & $\mathrm{mg} / \mathrm{l}$ & 3,0 & 1,47 & 11,5 & 0,02 & 1,59 \\
\hline & \multicolumn{7}{|l|}{ Mikrobiologi } \\
\hline 8 & $\begin{array}{l}\text { Total } \\
\text { Koliform }\end{array}$ & $\begin{array}{l}\text { MPN/ } \\
100 \mathrm{ml}\end{array}$ & 10 & 21 & 75 & 23 & 0 \\
\hline
\end{tabular}

Perbandingan Efektivitas Biji Kecipir dan Biji Asam Jawa sebagai Biokoagulan

Penentuan dosis optimum biokoagulan

biji kecipir dan biji asam jawa dengan menggunakan jar test diperoleh hasil yang berbeda. Dosis optimum yang dibutuhkan oleh biokoagulan biji asam jawa untuk menghasilkan persentase efektivitas penurunan turbiditas konsentrasinya lebih rendah dibandingkan dengan biji kecipir. Biokoagulan biji asam jawa dapat menurunkan turbiditas sebesar 99,72\% dengan dosis 0,009\% sedangkan biokoagulan biji kecipir menurunkan turbiditas sebesar 92,03 $\%$ dengan dosis $0,03 \%$.Hasil pengukuran terhadap parameter turbiditas, temperatur, $\mathrm{pH}$, konduktivitas, kadar logam, total koliform, dan oksigen terlarut dibandingkan Peraturan Pemerintah No. 82 Tahun 2001 Tentang Pengelolaan Kualitas Air dan Pengendalian Pencemaran Air dengan menggunakan kriteria mutu air kelas II dan Permenkes No.416 Tahun 1990 Tentang Syarat-syarat dan Pengawasan Kualitas Air.

Pada tabel 11 dapat diamati bahwa biokoagulan biji asam jawa menunjukkan hasil yang lebih baik dalam memperbaiki turbiditas, total koliform, serta logam besi dan mangan. Pada parameter BOD dengan biokoagulan biji asam jawa, masih memenuhi baku mutu walaupun terjadi peningkatan nilai BOD. Sedangkan untuk parameter temperatur, $\mathrm{pH}$, dan daya hantar, penambahan biokoagulan tidak memberikan perubahan yang berarti. Akan tetapi untuk parameter $\mathrm{pH}$ serta logam besi hasilnya belum memenuhi baku mutu yang dipersyaratkan.

\section{KESIMPULAN}

Berdasarkan hasil penelitian yang telah dilakukan, diperoleh kesimpulan sebagai berikut:

1. Penggunaan ekstrak biji Asam Jawa dan biji Kecipir tidak memberikan pengaruh yang berarti terhadap parameter temperatur, $\mathrm{pH}$, dan konduktivitas.

2. Ekstrak biji asam jawa dapat menurunkan turbiditas sebesar $99,72 \%$ dengan dosis $0,009 \%$ sedangkan ekstrak biji kecipir menurunkan turbiditas sebesar 92,03\% dengan dosis $0,03 \%$ masing-masing optimal pada $\mathrm{pH} 3$.

3. Penggunaan ekstrak biji asam jawa dan biji kecipir tidak menurunkan angka BOD juga kurang efektif untuk menurunkan kadar logam berat. Kadar logam Mn berkurang konsentrasinya sebesar $17,77 \%$ sedangkan pada logam $\mathrm{Fe}$ tidak terjadi penurunan konsentrasi.

4. Penggunaan ekstrak biji kecipir tidak menurunkan jumlah bakteri berdasarkan nilai indeks MPN per $100 \mathrm{~mL}$ sedangkan ekstrak biji asam jawa mampu menurunkan jumlah bakteri berdasarkan nilai indeks MPN per $100 \mathrm{~mL}$ dari 23 menjadi 9 (pH 6) dan pada pH 3 dari 23 menjadi nol. 
5. Setelah melalui proses koagulasi-flokulasi dengan ekstrak biji asam jawa dan biji kecipir, terdapat beberapa parameter uji yang belum memenuhi baku mutu air bersih yang dianjurkan yaitu $\mathrm{pH}$ dan kadar logam Fe.

6. Penggunaan ekstrak biji asam jawa dan biji kecipir tidak menurunkan kadar kandungan logam berat $\mathrm{Cd}, \mathrm{Cu}$, dan $\mathrm{Cr}$ dalam larutan logam simulasi.

\section{UCAPAN TERIMA KASIH}

Penulis mengucapkan terima kasih kepada Rektor UIN Syarif Hidayatullah Jakarta, Dekan Fakultas Sains dan Teknologi, dan Kepala Prodi Kimia Fakultas Sains dan Teknologi atas kesempatan yang diberikan kepada penulis untuk melaksanakan penelitian. Penulis juga mengucapkan terima kasih kepada Kepala PLT UIN Syarif Hidayatullah Jakarta, dan Kepala Laboratorium Balai Teknologi Lingkungan (BTL)-BPPT Serpong atas fasilitas yang diberikan selama penulis melaksanakan penelitian.

\section{Daftar Pustaka}

Amoo, I.A., O.T. Adebayo, and A.O. Oyeleye. 2006. Chemical Evaluation of Winged Bean (Psophocarpus tetragonolobus) Phitanga Cherries (Eugenia uniflora), and Orchid Fruit (Orchid Fruit myristica). African Journal of Food Agriculture Nutrition and Development Volume 6 No. 22006 ISSN 1684-5374. Nairobi: Rural Outreach Program.

Babu, Raveendra., and Malay Chauduri. 2005. Home Water Treatment by Direct Filtration with Natural Coagulant. Journal of Water and Health. India: IWA Publishing.

Bina, B., M.H. Mehdinejad, Gunnel Dalhammer, Guna Rajarao, M. Nikaeen, and $\mathrm{H}$. Movahedian Attar. 2010. Effectiveness of Moringa oleifera Coagulant Protein as Natural Coagulant Aid in Removal of Turbidity and Bacteria from Turbid Waters.World Academy of Science, Engineering and Technology 672010.

Campbell, Arezoo. 2002. The Potential Role of Aluminium in Alzheimer's Disease. Neprhol Dial transplant (2002) 17 [Suppl 2]: 17-20.

Dobrynin, Andrey V. dan Michael Rubinstein. 2005. Theory of polyelectrolytes in solutions and at surfaces. Prog. Polym. Sci. 30 (2005) 1049 1118. www.elsevier.com/locate/ppolysci.

Enrico, Bernard. 2008. Pemanfaatan Biji Asam Jawa (Tamarindus indica) sebagai Koagulan Alternatif dalam Proses Penjernihan Limbah Cair Industri Tahu. Tesis. Medan: Sekolah Pascasarjan Universitas Sumatera Utara.

Foidl N., Makkar H.P.S., dan Becker K. The Potential of Moringa Oleifera for Agricultural and Industrial Uses. http://www.moringa.co.il/Portals/7/Moringa_ FoidlEn.pdf, diakses pada 13 Maret 2011.

Imbabi, E.S., Ibrahim, K.E., Ahmed, B.M., Abulefuthu, I.M., Hulbert, P. 1992. Chemical Characterisation of The Tamarind Bitter Principle, Tamarindineal. Fitoterapia 63.

Maier, Raina M., Ian L. Pepper, and Charles P. Gebra. 2009. Environmental Microbiology, Second Edition. California: Academic Press.

Peraturan Menteri Kesehatan Nomor 416 Tahun 1990 Tentang Syarat-syarat dan Pengawasan Kualitas Air.

Peraturan Pemerintah Republik Indonesia Nomor 82 Tahun 2001 Tanggal 14 Desember 2001 Tentang Pengelolaan Kualitas Air dan Pengendalian Pencemaran Air.

Pernitsky, David J. 2003. Coagulation. Alberta: Assosiated Engeenering. https://awwoa.ab.ca/pdfs/Coagulation\%2010 1.pdf

Saefudin, Miranti Aryani, dan Tina Safaria. 2006. Efektivitas Biokoagulan Kacang Babi (Vicia faba) Dalam Memperbaiki Sifat Fisik dan Kimiawi Limbah Cair dan Industri Pulp dan Kertas. Laporan Penelitian. Bandung: UPI.

Said, Nusa Idaman., dan Ruliasih. 2010. Pengolahan Air Sungai Skala Rumah Tangga Secara Kontinyu. Jakarta: BPPT.

Salmin, 2005. Oksigen Terlarut (DO) dan Kebutuhan Oksigen Biologi (BOD) Sebagai Salah Satu Indikator Untuk Menentukan Kualitas Perairan. Oseana, Volume XXX, Nomor 3, 2005 : 21 - 26. Jakarta: LIPI.

Suriawiria, Unus. 2008. Mikrobiologi Air dan Dasar-dasar Pengolahan Buangan Secara Biologis. Bandung: P.T. Alumni.

Yuliastri, Indra Rani., dan Hendrawati. 2010. Penggunaan Serbuk Biji Kelor (Moringa oleifera) Sebagai Koagulan dan Flokulan dalam Perbaikan Kualitas Air Limbah dan Air Tanah. Skripsi. Jakarta: UIN Syarif Hidayatullah. 